\title{
UNDERGRADUATE STUDENTS' SELF-EFFICACY IN USING ENGLISH TO COMMUNICATE AS A SECOND LANGUAGE
}

\author{
L.J. Lee ${ }^{1}$, A.S. Shminan', S. Bujang ${ }^{1}$, M.H. Barawi ${ }^{1}$, M.A/L. Rathakrishnan² \\ ${ }^{1}$ Universiti Malaysia Sarawak (MALAYSIA) \\ ${ }^{2}$ Universiti Utara Malaysia (MALAYSIA)
}

\begin{abstract}
Although undergraduate students have been learning English for many years, ever since they were in primary school, some of them still could not be able to communicate or speak confidently and fluently in English. Speaking fluently in the English language seems difficult and challenging for them despite the fact that they are aware mastering this language is an added value especially when entering the job market. The purposes of this study were to investigate the relationship between undergraduate students' self-efficacy to communicate in English and their academic achievement, and to explore their self-efficacy to communicate in English in terms of aspiration, attitude and aptitude. Using a simple random sampling technique, 855 Malaysian final year undergraduate students from science major faculties and social science major faculties were given self-efficacy questionnaire of whom 87 also participated in an interview. The data collected were analyzed using descriptive and inferential statistics. The results showed that participants in this study had high self-efficacy beliefs in terms of their aspiration followed by attitude and aptitude. It was also found that science major faculty's students had significantly higher self-efficacy to communicate in English in terms of aspiration, attitude and aptitude than those in social science major faculty's students. Besides that, the analysis of correlation revealed that there is a significant correlation between the student's self-efficacy to communicate in English in terms of aspiration and student's academic achievement. Limitations of the study and implications for teaching and learning of the English language as a second language are also discussed.
\end{abstract}

Keywords: English Language, Self-Efficacy, Aspiration, Attitude and Aptitude.

\section{INTRODUCTION}

After their graduation, most of university students in Malaysia will enter the so called job or labor market, be it in the government or the private sector. In the contemporary and the current labor market, one of the main requirements for employees is to be able to communicate well and be able to show proper competence in English language. This is to make sure that they are able to react accordingly to the demands of globalization and rapid technological change [18]. Even though they do not have much experience, some industries, companies and even the government sectors still prefer to look for job candidates who can speak confidently and fluently in English. Whether they like it or not, university students have to accept the fact that speaking confidently and fluently in English is an advantage and useful as it is part of communication skills that one must mastered especially in today's globalized era. Be able to speak confidently and fluently in English may in away enable life-enriching experiences such as travelling, studying and working especially in countries where English is widely spoken.

While they were studying in a university, some undergraduate students may seem to realize that they will have more choices in their career options and look more attractive as a job candidate if they are able to speak confidently and fluently in English. Thus, it is not surprising that even some of them may have an ambition and dream to be able to speak confidently and fluently in English. Yet, if university students do not have strong or high self-efficacy to speak confidently and fluently in English, the process of improving their spoken English may become an obstacle and difficult. Self-efficacy is an individual's belief in their own ability to achieve anything. According to Bandura [2],[3] self-efficacy is people's judgement of their capabilities to establish and execute or perform courses of action required to achieve/accomplish designated types of performances. Therefore, self-efficacy has a significant influence on human behavior and affect in goal setting, effort, and level of persistence in facing daily tasks[17]. Besides that, self-efficacy helps to determine what individuals do with the knowledge and skill they have in order to produce or come out with desirable outcomes. Any individual who has high self-efficacy strongly believes in his/her competence, view difficult tasks/things as challenges and will 